\title{
Development of ATO as an alternative catalyst support for PEM fuel cells
}

\author{
N Mkhabela ${ }^{1, a}$, T Ngwenya ${ }^{1,2, b}$ \\ ${ }^{1}$ Mintek, Advanced Materials Division, 200 Malibongwe Drive, Randburg 2125, South Africa \\ ${ }^{2}$ HySA Catalysis, South Africa \\ Email: ${ }^{a}$ NkatekoM@mintek.co.za, ${ }^{b}$ ThelmaN@mintek.co.za*
}

\begin{abstract}
Proton exchange membrane (PEM) fuel cells demonstrated to be feasible energy converters that convert chemical energy of fuels to electrical energy. The technology has proven to be competitive with conventional energy converters such as batteries and internal combustion engines. However; several challenges influence the commercialization of this technology which includes high costs, durability, and stability, which are contributed by the PEM fuel cell catalysts. Currently, the carbon-supported platinum electro-catalyst is being used. Unfortunately, carbon supports are not stable enough for fuel cell durability due to carbon corrosion on the cathode. Therefore it is necessary to replace carbon support materials to improve the durability of PEM fuel cells. In this study, antimony doped tin oxide (ATO) metal oxides are synthesized as alternative platinum catalyst support via co-precipitation with different antimony doping levels of 5,7, and $10 \%$. The preliminary results of the acid resistance test show that the support is relatively acid-resistant with minor loss of dopant in acidic conditions. Surface area measurements, XRD, TEM, ICP characterization will be performed on the ATO before and after the addition of $40 \mathrm{wt}$. \% of Pt particles. The mass and specific activity measurements for oxygen reduction reaction (ORR) and durability via ex-situ thin-fil rotating disc electrode (RDE) of Pt/ATO catalyst and the traditionally used Pt/C catalyst will be compared.
\end{abstract}

\section{Introduction}

Carbon supported platinum electro-catalysts are mostly used in proton exchange membrane (PEM) fuel cells. ${ }^{1,2}$ Fuels cells operate under high humidity, low $\mathrm{pH}$ and high potential. During start/stop conditions, the Pt on carbon catalyst deteriorates mostly on the cathode side. ${ }^{3,4}$ Carbon support corrosion is one of the causes of fuel cell performance degradation. ${ }^{5}$ The corrosion speeds up the agglomeration of $\mathrm{Pt}$ metal particles and decreases the effective $\mathrm{Pt}$ content resulting in the cell degradation. Materials with high durability, high surface area, high effective metal support interactions and electrical conductivity are required to potentially replace carbon supports. ${ }^{6}$ Metal oxides have gained attention due to their anti-corrosiveness, however, they may be unstable in acidic conditions. Among metal oxides, tin oxide has been found to be acid tolerant and thus attracted a lot of attention. ${ }^{7}$ Tin oxide is an n-type semiconductor with a wide energy gap of $3.6 \mathrm{eV} .^{8}$ The energy band gap of tin oxide can be reduced by doping it with antimony, fluorine and indium thus increasing its conductivity. Antimony doped tin oxide (ATO) has gained more attention due to high electrical conductivity, good stability and low cost.9,10 In this study, the aim was to develop ATO nanoparticles as an alternative platinum catalyst support synthesised using co-precipitation method. The performance of the ATO supported Pt was tested exsitu using thin-film RDE.

\section{Materials and methods}

\subsection{Materials and equipment}

Absolute ethanol was sourced from associated chemical enterprises (ACE's), hydrochloric acid $(\mathrm{HCl})(37 \%)$, nitric acid $\left(\mathrm{HNO}_{3}\right)$
(65\%), ethylene glycol, ammonium carbonate, tin tetrachloride pentahydrate $\left(\mathrm{SnCl}_{4} \cdot 5 \mathrm{H}_{2} \mathrm{O}\right)$, and antimony trichloride $\left(\mathrm{SbCl}_{3}\right)$, supplied by Sigma-Aldrich ${ }^{\circledR}$ were used as precursors for the antimony doped tin oxide synthesis. A magnetic hotplate stirrer was used for stirring and heating up. A Hettich Rotina 420 desktop centrifuge was used to separate the precipitate from the solution. The oven (Eco Therm) was used for drying and the furnace (AE furnace up to $1450^{\circ} \mathrm{C}$ ) was used for heat treatment.

\subsection{Experimental methods}

\subsubsection{ATO synthesis}

$5 \%$ ATO refers to ATO with a Sb doping level content of $5 \%$.

In this study, the co-precipitation (11) method was used to produce ATO. To synthesize $5 \%$ ATO, $0.342 \mathrm{~g}$ of $\mathrm{SbCl}_{3}$ was dissolved in $40 \mathrm{ml}$ of $32 \% \mathrm{HCl}$ in a flask and placed in an ice bath. $10 \mathrm{~g}$ of $\mathrm{SnCl}_{4} \cdot 5 \mathrm{H}_{2} \mathrm{O}$ was dissolved in high purity water and added dropwise to the $\mathrm{SbCl}_{3}$ solution. A clear solution was formed which was stirred for $30 \mathrm{~min}$. Dilute $\mathrm{NH}_{4} \mathrm{OH}$ solution was added to the solution to adjust the $\mathrm{pH}$ to 3.5 , which resulted in the formation of a white precipitate and this was stirred further for $15 \mathrm{~min}$. The precipitate was collected via centrifuge at 2000 RPM for $10 \mathrm{~min}$ and washed thoroughly with high purity water to remove $\mathrm{Cl}^{-}$. The precipitate was dried at $70^{\circ} \mathrm{C}$ in the oven for $24 \mathrm{~h}$ then ground into a powder and calcined in air at $600{ }^{\circ} \mathrm{C}$ for $2 \mathrm{~h}$.

\subsubsection{Synthesis of Pt/ATO}

$100 \mathrm{~mL}$ of ethylene glycol was mixed with $2 \mathrm{~g}$ of ATO support and stirred vigorously for $2 \mathrm{~h}$. It was followed by titrating $10 \mathrm{~mL}$ of chloroplatinic acid solution into the mixture. The $\mathrm{pH}$ of the mixture 
was adjusted to 3.5 using $1 \mathrm{M} \mathrm{NaOH}$ solution. The mixture was then heated slowly to $140{ }^{\circ} \mathrm{C}$ until the colour changed to dark grey/ black. The mixture was cooled to room temperature followed by stirring overnight. The precipitate was separated from the solution by centrifugation and it was dried at $70{ }^{\circ} \mathrm{C}$ overnight. The Pt/ATO catalyst was thermally pre-treated in the furnace in a mixture of $\mathrm{N}_{2}$ (95\%) and $\mathrm{H}_{2}(5 \%)$ at a temperature of $600{ }^{\circ} \mathrm{C}$.

\subsection{Characterization}

\subsubsection{Acid resistance testing}

The ATO was tested for the resistance in an acidic environment by boiling $2 \mathrm{~g}$ of ATO in $10 \mathrm{ml}$ of $2 \mathrm{M} \mathrm{HNO}_{3}$ at $80{ }^{\circ} \mathrm{C}$ for $2 \mathrm{~h}$. This was then filtered thoroughly and the filtrate was analysed for the antimony concentration using ICP-OES. The antimony concentration in the fresh and acid ATO was also determined using ICP-OES technique.

\subsubsection{Analysis}

Transmission Electron Microscopy (TEM) was used for imaging and analysis of Pt/ATO. This was done at the University of Cape Town Imaging Centre. The Bruker D8 Advance diffractometer fitted with a Co K $\alpha$ source with a wavelength of $1.789 \AA$ was used to perform the $\mathrm{x}$-ray diffraction (XRD) on the ATO and Pt/ATO

\subsubsection{Ex-situ electrochemical testing}

The ex-situ electrochemical characterization of the Pt supported on ATO was determined using thin-film RDE. This was used to determine the Pt electrochemical surface area (ECSA) and the kinetic ORR activity. The catalyst layers was prepared by sonicating $15 \mathrm{mg}$ of catalyst in $10 \%$ ethanol solution for $20 \mathrm{~min}$. $20 \mu \mathrm{L}$ of the catalyst ink was then pipetted onto a clean $5 \mathrm{~mm}$ glassy carbon electrode to achieve a Pt loading of $56 \mu \mathrm{g}_{\mathrm{Pt}} / \mathrm{cm}^{2}{ }_{\mathrm{GC}} \cdot 20$ $\mu \mathrm{L}$ of Nafion ${ }^{\mathrm{TM}}$ solution was added to the catalyst layer and dried for $10 \mathrm{~min}$ at $120^{\circ} \mathrm{C}$.

The measurements were carried out using a three electrode cell in $0.1 \mathrm{M} \mathrm{HClO}_{4}$ with SCE as a reference electrode and a Pt strip as a counter electrode on an Autolab PGSTAT302N potentionstat using NOVA v1.5 software.

The Pt ECSA was determined by cyclic voltammetry in glass cell at $25{ }^{\circ} \mathrm{C}$ in nitrogen-purged $0.1 \mathrm{M} \mathrm{HClO}_{4}$. Prior to measuring the 3 cycles at $20 \mathrm{mV} / \mathrm{s}$ to determine the hydrogen adsorption charge, the catalyst layers were conditioned for 15 cycles at $50 \mathrm{mV} / \mathrm{s}$ by cycling the potential between 0 and $1.2 \mathrm{~V}_{\mathrm{RHE}}$. The ORR was also performed at $25{ }^{\circ} \mathrm{C}$ in oxygen-purged $0.1 \mathrm{M} \mathrm{HClO}_{4}$ while rotation the RDE at 1600 RPM.

\section{Results and discussion}

\subsection{Acid resistance test}

The Table 1 below show the concentration of the dopant $\mathrm{Sb}$ present in the filtrate after boiling ATO at $80{ }^{\circ} \mathrm{C}$ in $\mathrm{HNO}_{3}$.

As observed, the concentration of $\mathrm{Sb}$ in 10-ATO is higher than in 5-ATO showing that there was significant loss in Sb from the solid support as the doping level increased. This same trend was observed in earlier tests with a difference of $0.61 \mathrm{ppm}$ difference
Table 1: Sb concentration in ATO and filtrate after leaching with $\mathrm{HNO}_{3}$

\begin{tabular}{ccc}
\hline & $\begin{array}{c}\text { Doping level } \\
(\mathbf{\%})\end{array}$ & $\begin{array}{c}\text { Concentration in filtrate } \\
(\mathbf{p p m})\end{array}$ \\
\hline \multirow{2}{*}{ ATO } & 5 & 0.04 \\
& 10 & 0.39 \\
\hline
\end{tabular}

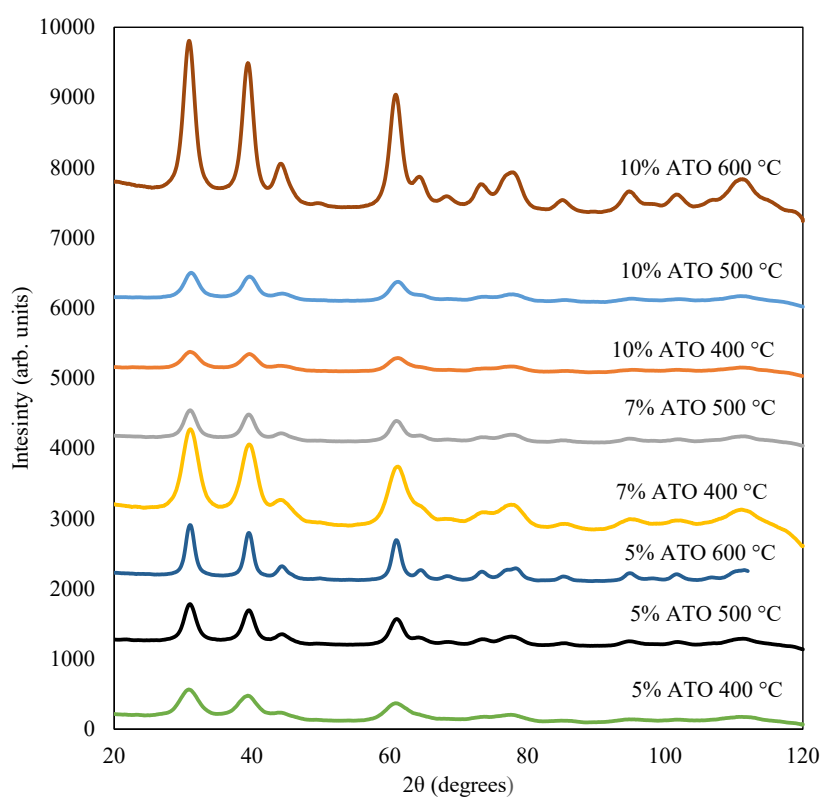

Figure 1: XRD peaks of 5, 7, and $10 \%$ ATO powders

between 5-ATO and 10-ATO. This can be attributed to the higher concentration of $\mathrm{Sb}$ at higher doping levels and thus show that $\mathrm{Sb}$ is leached from ATO in acidic conditions. The low acid resistance of ATO was also observed in earlier studies that suspected loss of $\mathrm{Sb}$ during the Pt loading stage which occurs at $\mathrm{pH}$ 2-3 on commercial ATO. ${ }^{12}$

\subsection{XRD analysis}

Figure 1 shows the x-ray diffraction patterns for ATO powders doped with $5 \%, 7 \%$ and $10 \%$ content of $\mathrm{Sb}$ in $\mathrm{SnO}_{2}$ after calcining at $400{ }^{\circ} \mathrm{C}, 500{ }^{\circ} \mathrm{C}$ and $600{ }^{\circ} \mathrm{C}$. Unfortunately XRD data for $7 \%$ ATO calcined at $600{ }^{\circ} \mathrm{C}$ could not be included in this due to lack of data. It can be seen that the partners of all ATO powders calcined at different temperatures presented the same characteristic peaks of a tetragonal rutile structure of cassiterite $\mathrm{SnO}_{2}$ with a space group of $\mathrm{P} 42 / \mathrm{mnm}$ (136), indicating that they had the same crystal structure. Varying the calcination temperature for the $5 \%$ and $10 \%$ ATO powder resulted on the gradually sharpening of diffraction peaks and the increase of the diffraction peaks intensity. The doping level of $\mathrm{Sb}$ in ATO did not change the crystal structure.

\subsection{Electrochemical testing}

The CV scans for $40 \mathrm{wt} \% \mathrm{Pt}$ on $10 \%$ ATO synthesized via coprecipitation are shown in Figure 2 with an ECSA of $6.4 \mathrm{~m}^{2} / \mathrm{gPt}$. The ORR measurements showed a specific and mass activity of $3.85 \mu \mathrm{A} / \mathrm{cm}^{2} \mathrm{Pt}$ and $0.19 \mathrm{~mA} / \mathrm{mgPt}$, respectively. It is suspected that the polyol binds onto the Pt reducing the catalyst activity thus catalyst activation is required. 


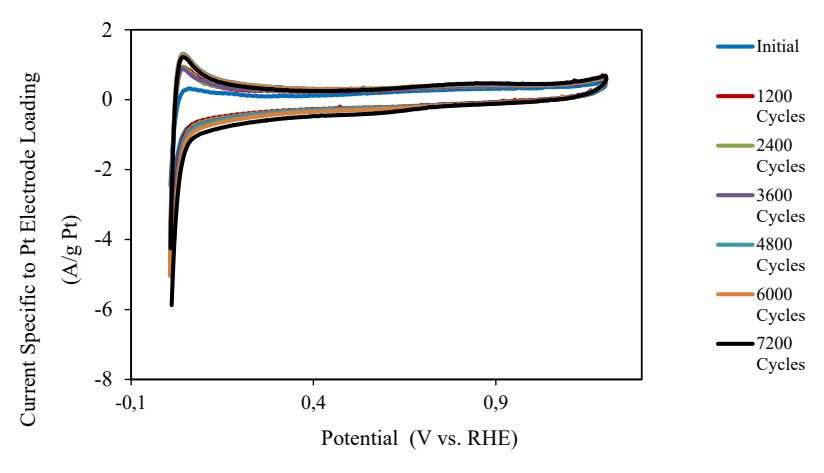

Figure 2: Accelerated durability tests for Pt/ATO

The durability tests show that there was an initial $28 \%$ loss of ECSA after 1200 cycles from $4.5 \mathrm{~m}^{2} / \mathrm{g}_{\mathrm{Pt}}$. This was followed by a $48 \%$ increase in the electrochemical surface area to $6.7 \mathrm{~m}^{2} / \mathrm{g}_{\mathrm{Pt}}$ after 7200 cycles. It is suspected that electrochemical corrosion of the $\mathrm{Pt}$ inhibitor occurs and/or activation of the Pt/ATO occurs on the electrode. This leads to the observed increase in ECSA as more active $\mathrm{Pt}$ nanoparticles are exposed. The $\mathrm{Pt} / \mathrm{C}$ durability test show a $35 \%$ loss of electrochemical surface area after 7200 cycles which was a decrease in ECSA from $75.7 \mathrm{~m}^{2} / \mathrm{g}_{\mathrm{Pt}}$ to $62.8 \mathrm{~m}^{2} / \mathrm{g}_{\mathrm{Pt}}$.

\section{Conclusions}

The synthesis of ATO via co-precipitation has been successful with the XRD data confirming tetragonal rutile structure for all ATO powders at different temperatures. As the temperature increased from 400 to $600{ }^{\circ} \mathrm{C}$ the diffraction peaks intensity increased and gradually sharpen. The ATO have also demonstrated reasonable resistance to the loss of antimony dopant in acidic conditions. Preliminary results of Pt loading shows that the method used in loading of $\mathrm{Pt}$ results in Pt/ATO catalyst that has an inhibitor (ethylene glycol) adsorbed onto the Pt reducing the ECSA as shown in the CV scans and ADT. Therefore, further activation of the catalyst may need to be performed to increase the activity. BET, TEM, ICP-OES and electrochemical testing characterisation on ATO and Pt/ATO still needs to be analysed.

\section{Acknowledgements}

The authors gratefully acknowledge support from Mintek and HySA under catalysis project No. ADE32101 for financial support.

\section{References}

1. Dicks AL. The role of carbon in fuel cells. J Power Sources. 2006;156(2):128-41.

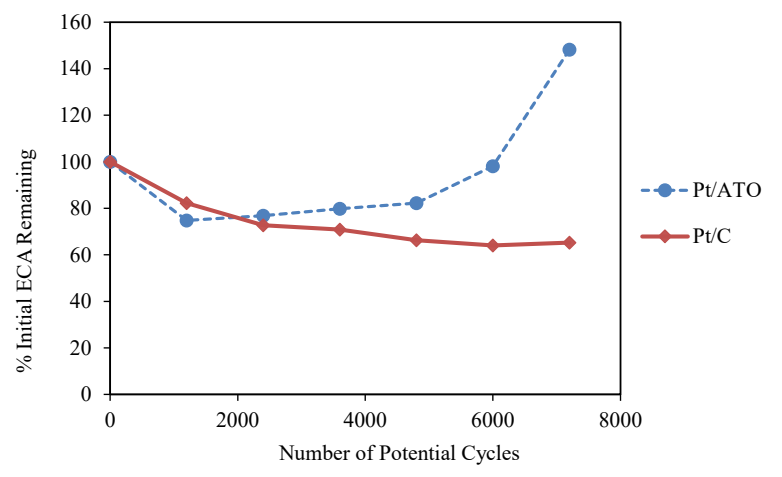

Figure 3: Loss/gain in ECSA of Pt/ATO and Pt/C over 7200 cycles

2. Othman R, Dicks AL, Zhu Z. Non precious metal catalysts for the PEM fuel cell cathode. Int $\mathrm{J}$ Hydrogen Energy [Internet]. 2012;37(1):357-72. Available from: http://dx.doi.org/10.1016/j. ijhydene.2011.08.095

3. Vinayan BP, Jafri RI, Nagar R, Rajalakshmi N, Sethupathi K, Ramaprabhu S. Catalytic activity of platinum-cobalt alloy nanoparticles decorated functionalized multiwalled carbon nanotubes for oxygen reduction reaction in PEMFC. Int J Hydrogen Energy [Internet]. 2012;37(1):412-21. Available from: http://dx.doi org/10.1016/j.ijhydene.2011.09.069

4. Zhao J. Catalyst Layers in Polymer Electrolyte Membrane Fuel Cells: Formation, Characterization and Performance. 2019; Available from: https://uwspace.uwaterloo.ca/handle/10012/14425

5. Chen Z, Hsu R. Catalyst support degradation. PEM Fuel Cell Failure Mode Analysis. 2011. 33-72 p.

6. Mohanta PK, Glökler C, Arenas AO, Jörissen L. Sb doped $\mathrm{SnO}_{2}$ as a stable cathode catalyst support for low temperature polymer electrolyte membrane fuel cell. Int J Hydrogen Energy. 2017;42(46):27950-61.

7. Zhao Q, Ma L, Zhang Q, Wang $\mathrm{C}, \mathrm{Xu} \mathrm{X}$. $\mathrm{SnO}_{2}$-Based Nanomaterials: Synthesis and Application in Lithium-Ion Batteries and Supercapacitors. J Nanomater. 2015;2015(1).

8. Li Y, Wang J, Feng B, Duan K, Weng J. Synthesis and characterization of antimony-doped tin oxide (ATO) nanoparticles with high conductivity using a facile ammonia-diffusion co-precipitation method. J Alloys Compd [Internet]. 2015;634:37-42. Available from: http://dx.doi.org/10.1016/j.jallcom.2015.02.060

9. Ganose AM, Scanlon DO. Band gap and work function tailoring of $\mathrm{SnO}_{2}$ for improved transparent conducting ability in photovoltaics. J Mater Chem C. 2016;4(7):1467-75.

10. Ponja SD, Williamson BAD, Sathasivam S, Scanlon DO, Parkin IP, Carmalt CJ. Enhanced electrical properties of antimony doped tin oxide thin films deposited: Via aerosol assisted chemical vapour deposition. J Mater Chem C. 2018;6(27):7257-66.

11. Li YQ, Wang JL, Fu SY, Mei SG, Zhang JM, Yong K. Facile synthesis of antimony-doped tin oxide nanoparticles by a polymer-pyrolysis method. Mater Res Bull [Internet]. 2010;45(6):677-81. Available from: http://dx.doi.org/10.1016/j.materresbull.2010.03.003

12. Stevenson ML, Pattrick G, Papo MJ. Development and scale-up of platinum fuel cell catalysts. 2015. Mintek (Internal report). 